[SHORT COMUNICATION]

\section{Resistance to the Pinewood Nematode in Seedlings Obtained from Resistant Clonal Seed Orchards}

\author{
Kazutaka KATO* \\ Kaichiroo KAWAMURA* \\ and Chuuji UEKI*
}

\section{INTRODUCTION}

Severe damage of pines caused by the pinewood nematode (Brusaphelenchus xylophilus (STEINER et BuHRER) NiCKLE) spread from the south-western part to the eastern part of Japan during the past twenty years. A project for resistance breeding against pine wilt disease was initiated in 1978 at the Forest Tree Breeding Institute as a national project. In this project, 92 clones of red pine (Pinus densiflora SIEB. et ZuCC.) and 16 of black pine ( $P$. thunbergii PARL) which were resistant to the nematode were selected by the end of $1984(2,3,4)$, and clonal seed orchards were established in 21 prefectures and at three Forest Tree Breeding Institutes (Kansai, Shikoku and Kyushu). However, the factors controlling the resistance to the pinewood nematode in the offsprings of resistant clones have not been well documented yet (5)

At the Kansai and Shikoku Forest Tree Breeding Institute, open-pollinated seeds from the clonal seed orchards have been collected since 1990, and a crossing project has been initiated to develop combined characteristic families (especially families that

*Kansai Breeding Office, Forest Tree Breeding Institute, 1043 Uetsukinaka, Shoo, Okayama, 709 -43 Japan. are resistant to the pinewood nematode and are categorized by fast growth) since 1989. Until now, artificial inoculation test of the pinewood nematode had been conducted on open-pollinated families from 111 clones planted in the clonal seed orchards and on 57 combined families by artificial crossing in 1992 and 1993.

In this paper, we summarized the results of survival rates of open-pollinated and crossed families, and discussed the mode of transmission of the resistance to the pinewood nematode.

\section{MATERIALS AND METHODS}

Investigations were conducted at the Kansai, (35 $3^{\prime} \mathrm{N}$ and $134^{\circ} 6^{\prime} \mathrm{E}$ ) and Shikoku $\left(33^{\circ} 36^{\prime} \mathrm{N}\right.$ and $\left.133^{\circ} 42^{\prime} \mathrm{E}\right)$ Forest Tree Breeding Institute. Fifty seven combined families and 118 open-pollinated families including five elite clones and four foreign pine species (P. massoniana, P. tabulaeformis, $P$. teada and $P$. pungens) were selected for inoculation. In the resistant clonal seed orchards, 10 ramets of each $P$. densiflora clone and 5 ramets of each $P$. thunbergii clone with resistance to the pinewood nematode were planted in both locations. Although the possibility of crossing with elite trees $(\mathrm{ET}) \times$ resistant trees (RT) in the clonal seed orchards may be nil, crossing among resistant clones of $P$. densiflora and $P$. thunbergii may occur because the clonal seed orchards of the two species were adjacent to each other in both locations. Sampled seedlings inoculated numbered 15, 394 in total. In the two locations, about half of open-pollinated seeds were taken twice from ramets of the same resistant trees.

Artificial crossing was conducted in the spring of 1989 and 1990 at Shikoku F. M. using pollen from two ET clones, three foreign pine species and four pine clones resistant to the pinewood nematode. All the 
collected seeds were sown in a nursery in 1990 and 1991. The number of tested seedlings from each family ranged from 2 to 150 . Artificial inoculation test of the pinewood nematode was conducted in 3-year-old seedlings at the Kansai Institute and 2-year-old seedlings at Shikoku Institute. The pinewood nematodes were collected from $P$. densiflora trees infested with them at the Kansai Institute in 1991, and they were cultured for inoculation in petri dishes with PDA medium. The bark of the 2-year-old part of the leader shoot of each seedling was peeled (one by 5 $\mathrm{cm}$ ) and scratched with a knife and a small saw, leading to the formation of a scar similar to that resulting from feeding by an adult Japanese pine sawyer (Monochamus alter. natus HoPE), and then a $0.1 \mathrm{ml}(0.2 \mathrm{ml}$ for 3 -year-old seedlings) inoculum suspension containing 10000 nematodes was dropped onto the peeled part with a micro-pipet from late July to early August, 1992 or 1993. Eight weeks after the inoculation, number of dead trees was counted for each family and the survival rate was evaluated.

\section{RESULTS AND DISCUSSION}

Figure 1 shows the number of open-pollinated families of ET and RT classified into 7 levels of survival rate range. The survival rates in both 1992 and 1993 were generally higher compared with the results reported by OKADA and TSUDA (2), TAKEUCHI et al.(3), and TODA et al.(4). This difference can be ascribed to the fact that the larger amount of precipitation may have resulted in higher rates (1); namely the precipitation in August 1992 and 1993 was three times higher than the mean precipitation of the recent ten years in Kansai Institute and Shikoku Institute. The survival rate of the open-pollinated families from two ET clones used for the crosses as paternal parent was extremely low at Shikoku F. M. in 1992 (11\% and 18\%), suggesting that the virulence of the nematodes was not reduced at the time of the inoculation. Though the mean survival rate of the openpollinated ET families was significantly

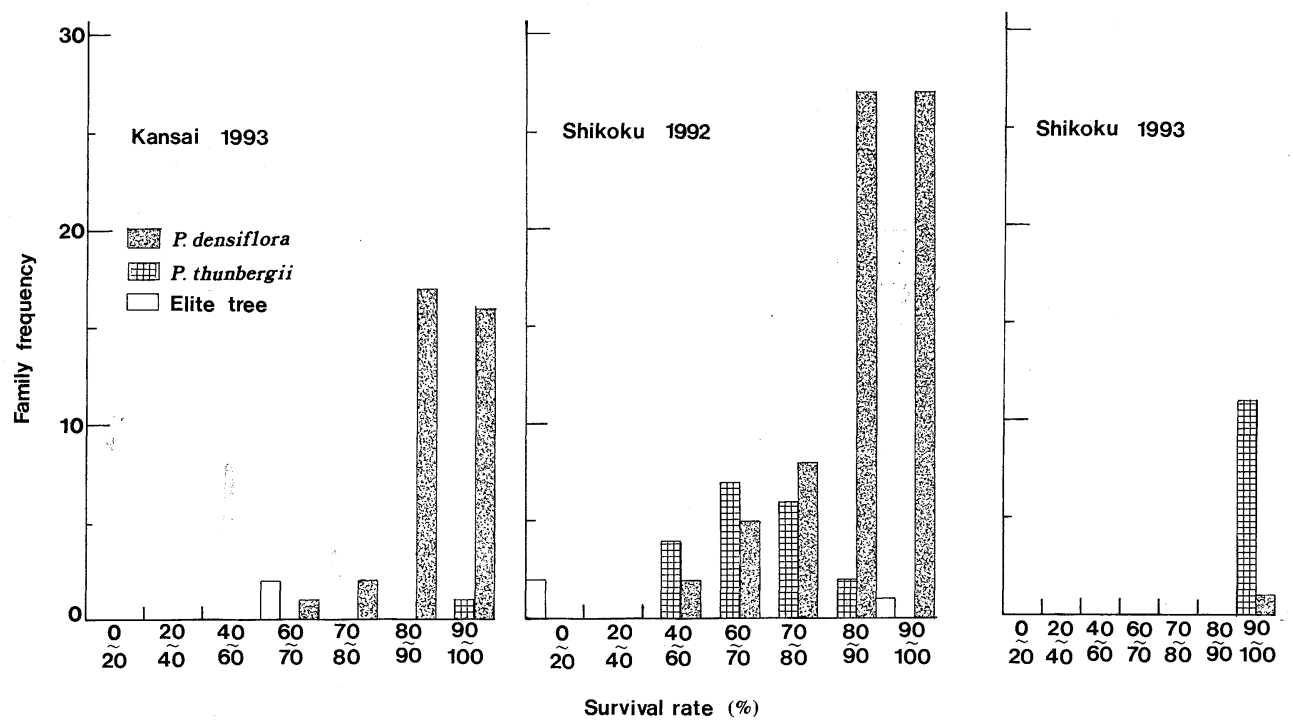

Fig. 1 Frequency distribution of open-pollinated families classified into 7 levels of survival rate range. $P$. densiflora and $P$. thunbergii are RT trees. Seven levels of survival rate are as follows: $<20,20 \leqq \sim<40,40 \leqq \sim<60, \leqq 60 \sim<70,70 \leqq \sim<80,80 \leqq \sim<90$ and $90 \leqq \sim \leqq 100(\%)$. 
lower than that of open pollinated RT families at the Kansai Institute in 1993 (Cochran- Cox $t=6.48, \mathrm{df}=38, p<0.05$ ), the correlation was not significant between them at Shikoku F. M. in 1992 (CoCHRAN-Cox $t=$ $1.33, \mathrm{df}=91, p>0.05$ ), because one ET family showed a high survival rate at Shikoku F. M. in 1992. The survival rates of the RT families of $P$. densiflora were significantly lower than those of the RT families of $P$. thunbergii at Shikoku F. M. in $1992(t=6.21, p<0.001)$.

The mean survival rate of the crossed families $(\mathrm{RT} \times \mathrm{ET})$ was significantly lower than that of the crossed families $(\mathrm{RT} \times \mathrm{RT})$ at Shikoku F. M. in $1993(t=2.52, \mathrm{df}=27, p<$ 0.05 ) (Fig. 2), suggesting that the resistance to the pinewood nematode is transmitted with a high frequency if both parents are resistant.

Survival rates of foreign pine trees were widely spread between mating systems or cross combinations at Shikoku F. M. in 1992 (Table 1). On the other hand, the survival rates were high for all the families at Shikoku F. M. in 1993.
TODA et al.(5) who reported that the degree of family resistance varied with years suggested that environmental factors may influence the expression of resistance. In this study, there was no correlation in the survival rate of open-pollinated RT families, firstly between the rates at Kansai Institute and Shikoku Institute in $1993(n=20, \mathrm{KEN}$ DALL's $\tau=0.02, p>0.05$ ), and also between those in 1992 and 1993 at Shikoku F. M. ( $n=$ 10 , Kendall's $\tau=0.20, p>0.05)$. These results suggest that the degree of family resistance varied with years and between locations. However, the reproductivity of the family resistance of RT was high because the mean survival rate of the open-pollinated resistant families (RT) was higher than that of $P$. taeda, which is practically resistant to the nematode, at Shikoku F. M. in 1992. Therefore, the seeds from clonal seed orchards that are resistant to the pinewood nematode could be used practically.

On the other hand, the resistance of the pine trees to the pinewood nematode may not be adequately transmitted to the offspring if

Table 1. Number of families in each survival rate range (inoculation of pinewood nematode using four foreign pine species).

\begin{tabular}{|c|c|c|c|c|c|c|c|}
\hline \multirow{2}{*}{$\begin{array}{l}\text { Tested } \\
\text { location }\end{array}$} & \multirow{2}{*}{ Year } & \multirow{2}{*}{$\begin{array}{c}\text { Mating system or } \\
\text { cross combination } \\
\left(\text { 우 } \times 0^{\top}\right)\end{array}$} & \multicolumn{5}{|c|}{ Family survival rate (\%) } \\
\hline & & & $0-20$ & $20-40$ & $40-60$ & $60-80$ & $80-100$ \\
\hline \multirow{8}{*}{ Shikoku } & \multirow{8}{*}{1992} & $\mathrm{~F} 1 \times P$. massoniana & 0 & 0 & 0 & 0 & 2 \\
\hline & & $\mathrm{F} 1 \times \mathrm{RT}$ & 0 & 0 & 2 & 0 & 0 \\
\hline & & $\mathrm{RT} \times P$. massoniana & 0 & 0 & 3 & 2 & 2 \\
\hline & & $\mathrm{RT} \times P$. tabulaeformis & 0 & 1 & 1 & 1 & 0 \\
\hline & & $\mathrm{F} 1(\mathrm{OP})$ & 0 & 2 & 1 & 1 & 0 \\
\hline & & P. massoniana (OP) & 0 & 0 & 0 & 0 & 1 \\
\hline & & P. taeda (OP) & 0 & 0 & 0 & 1 & 0 \\
\hline & & P. pungens (OP) & 0 & 0 & 0 & 0 & 1 \\
\hline \multirow{4}{*}{ Shikoku } & \multirow{4}{*}{1993} & $\mathrm{RT} \times P$. massoniana & 0 & 0 & 0 & 0 & 6 \\
\hline & & $\mathrm{RT} \times P$. tabulaeformis & 0 & 0 & 0 & 0 & 2 \\
\hline & & $\mathrm{RT} \times \mathrm{F} 1$ & 0 & 0 & 0 & 0 & 2 \\
\hline & & P. tabulaeformis $\times \mathrm{RT}$ & 0 & 0 & 0 & 0 & 1 \\
\hline
\end{tabular}

RT: Resistant trees to pinwood nematode ( $P$. densiflora or $P$. thunbergii).

F1: Trees resulting from crossing between elite trees $(P$. densiflora or $P$. thunbergii $) \times P$. tabulaeformis.

OP: Open-pollinated families. 

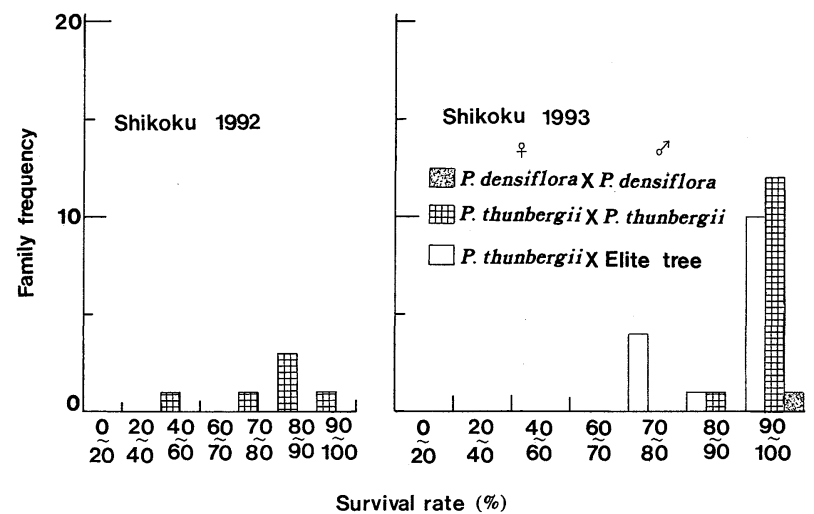

Fig. 2 Frequency distribution of crossed families classified into 7 levels of survival rate range. $P$. densiflora and $P$. thunbergii are RT trees. Seven levels of survival rate are as follows: $<20,20 \leqq \sim<40,40 \leqq \sim<60,60 \leqq \sim<70,70 \leqq \sim<80,80 \leqq \sim<90$ and $90 \leqq \sim \leqq 100$ (\%).

only the maternal parent is resistant to the pinewood nematode (Fig. 2). Therefore, this observation and the difference in the order of survival rates between years and/or locations suggest that multiple genes are involved in the resistance. If this is the case, artificial crossing of RT clones could produce families with higher resistance. Further studies should be carried out to address the problems of stability of family resistance and breeding of combined characteristic families because annual environmental factors may considerably affect the expression of resistance.

\section{REFERENCES}

1) Fujimoto, Y., Toda, T., Nishimura, K., Yamate, H. \& Fuyuno, S. (1989) Bull. For. Tree Breed. Inst. 7, 1-84 (In Japanese with English summary).

2 ) OKAdA, S. \& TsudA, T. (1989) Bull. For. Tree Breed. Inst. 7, 85-118 (In Japanese with English summary).

3 ) Takeuchi, H., Handa, T., Ohguro, T. \& Okamura, M. (1989) Bull. For. Tree Breed. Inst. 7, 119-143 (In Japanese with English summary).

4 ) Toda, T., Fujimoto, Y., Nishimura, K., Yamate, H. \& Fuyuno, S. (1989) Bull.
For. Tree Breed. Inst. 7, 119-143 (In Japanese with English summary).

5 ) Toda, T., Tajima, M., Nishimura, K. \& Takeuchi, H. (1993) Bull. For. Tree Breed. Inst. 11, 37-88 (In Japanese with English summary).

Accepted for publication: September 2, 1994

\section{和文摘要}

\section{採種園から得られた実生苗のマツノザイ センチュウに対する抵抗性}

\section{加藤 一隆・河村嘉一郎・植木 忠二}

採種園から採種した自然受粉および人工交配 による種子からの実生苗に、マツノザイセン チュウを人工接種し、その抵抗性を調べた。そ の結果、マツノザイセンチュウ抵抗性クローン の自然受粉家系は、精英樹の自然受粉家系より もザイセンチュウに対する抵抗性は高く、また 抵抗性個体 $\times$ 抵抗性個体の家系は、抵抗性個 体 $\times$ 精英樹個体家系よりも抵抗性は高かった。 このことは、両親ともに抵抗性を持ち合わせて いる方が、抵抗性は確実に後代に伝わることが 示唆された。 